\title{
Extinction of tyrosine aminotransferase gene activity in somatic cell hybrids involves modification and loss of several essential transcriptional activators
}

\author{
Doris Nitsch, Michael Boshart, ${ }^{1}$ and Günther Schütz ${ }^{2}$ \\ Divison of Molecular Biology of the Cell I, German Cancer Research Center, D-6900 Heidelberg, Germany
}

\begin{abstract}
Extinction is defined as the loss of cell type-specific gene expression that occurs in somatic cell hybrids derived by fusion of cells with dissimilar phenotypes. To explore the basis of this dominant-negative regulation, we have studied the activities of the control elements of the liver-specific gene encoding tyrosine aminotransferase (TAT) in hepatoma/fibroblast hybrid crosses. We show that extinction in complete somatic cell hybrids is accompanied by the loss of activity of all known cell type-specific control elements of the TAT gene. This inactivity is the result of first, lack of expression of genes coding for the transcriptional activators HNF4 and HNF3 $\beta$ and HNF3 $\gamma$, which bind to essential elements of the enhancers; and second, loss of in vivo binding and activity of ubiquitous factors to these enhancers, including CREB, which is the target for repression by the tissue-specific extinguisher locus TSE1. Complete extinction of TAT gene activity is therefore a multifactorial process affecting all three enhancers controlling liver-specific and hormone-inducible expression. It results from lack of activation, rather than active repression, and involves both post-translational modification and loss of essential transcriptional activators.
\end{abstract}

[Key Words: Extinction; tyrosine aminotransferase; chromatin; HNF3; HNF4; somatic cell hybrids]

Received September 14, 1992; revised version accepted November 23, 1992.

A particular cellular phenotype, characterized by the expression of distinct sets of genes, is thought to be determined by the action of positively and negatively acting regulatory proteins. This combinatorial control of gene activity involves the binding of multiple trans-acting factors to distinct cis regulatory elements. The differentiated state usually has to be actively maintained and continually transmitted (for review, see Blau 1992). Striking examples for this requirement of continual regulation are presented by the autoregulatory loops discovered in the maintenance of the muscle phenotype involving MyoD as a positive regulator (for review, see Weintraub et al. 1991) and by proteins of the polycomb group, among which are negative regulators required for differential expression of homeotic genes along the anteriorposterior axis of the Drosophila embryo (for review, see Paro 1990).

Whereas many cell type-specific positive regulators have been characterized, the role of negatively acting regulatory proteins in specifying a particular cellular phenotype is less clear, although several examples of repressor-like activities have been described (for review,

${ }^{1}$ Present address: Max-Planck Institute of Biochemistry, Genzentrum, D-8033 Martinsried, Germany.

${ }^{2}$ Corresponding author. see Renkawitz 1990). In particular, the importance of negative control in animal cells has been postulated on the strength of studies of gene expression in cellular hybrids in which the phenotype of extinction is often observed. Extinction of gene activity occurs when cells of different phenotypes are fused. It has been observed in fusions involving many cell types and usually results in loss of the cell type-specific expression patterns of both parental cells (Davidson 1974; Weiss et al. 1988; Gourdeau and Fournier 1990 and references therein). The phenomenon of extinction is therefore general and bidirectional.

Studies of hepatoma derived cell hybrids revealed that extinction has a genetic basis: First, extinguished liver functions can be re-expressed in hybrid segregants that have lost chromosomes derived from the nonhepatic parent, indicating that extinction is reversible and is mediated by regulatory factors that negatively affect gene activity in trans (Weiss and Chaplain 1971; Weiss et al. 1975; Peterson et al. 1985; Chin and Fournier 1987). Second, in hepatoma microcell hybrids, which contain only one or few fibroblast chromosomes, the extinction of subsets of liver genes can be correlated with the retention of specific nonhepatic chromosomes, an observation that has led to the definition of so-called tissue-specific extinguisher (TSE) loci (Killary and Fournier 1984; Petit 
et al. 1986; Chin and Fournier 1989). The reversibility of the active and inactive state of a particular gene attests to the above-mentioned notion that both activation and extinction are processes that are actively maintained.

Analyses of microcell hybrids containing parts of the long arm of fibroblast-derived human chromosome 17 in a hepatoma cell background have defined an extinguisher locus that influences many or possibly all cAMPregulated liver functions, including expression of the tyrosine aminotransferase (TAT) and phosphoenol pyruvate carboxykinase (PEPCK) genes (TSE1; Killary and Fournier 1984; Lem et al. 1988; Thayer and Fournier 1989; Ruppert et al. 1990). Recently, we identified a cAMP response element (CRE) in a liver-specific enhancer of the TAT gene as the target of TSEl-dependent extinction (Boshart et al. 1990) and, subsequently, showed TSE 1 to be the regulatory subunit RI $\alpha$ of protein kinase A (Boshart et al. 1991a; Jones et al. 1991). As an inhibitory component of the cAMP signaling pathway, TSE1 interferes with phosphorylation of the CRE binding protein (CREB) by protein kinase $A$ and prevents its binding to and activation of an essential enhancer element of the TAT gene. Thus far, TSE1 is the only example in which the mechanism of action of an extinguisher locus has been elucidated. Analyses in other systems have documented that extinction in somatic cell hybrids is accompanied by loss of individual tissue-specific transcription factors (Baumhueter et al. 1988; Cereghini et al. 1988, 1990; McCormick et al. 1988, 1990; Bergman et al. 1990; Junker et al. 1990; Bulla et al. 1992).

Whereas in monochromosomal hybrids, containing an active fibroblast-derived TSE1 locus, only a subset of liver genes are extinguished, in whole-cell hybrids all liver-specific functions are affected (Chin and Fournier 1987; Lem et al. 1988; Ruppert et al. 1990). Moreover, comparison of TAT gene activity in these two hybrid systems has indicated striking quantitative and qualitative differences. Whereas TAT gene expression is reduced $\leqslant 20$-fold by the action of TSE 1 in monochromosomal hybrids and fully reversible by administration of cAMP, it is shut off by about three orders of magnitude and is not cAMP inducible in whole-cell hybrids (Thayer and Fournier 1989). In this study we have tested whether the difference between whole cell and monochromosomal hybrids reflects the action of multiple genetic controls operating through different trans-acting factors involved in the cell-specific regulation of TAT gene expression.

Recent studies from our laboratory have defined three liver cell-specific enhancers of the rat TAT gene, two of which are dependent on signals from the cAMP or glucocorticoid signaling pathways. The glucocorticoid-inducible enhancer is located $2.5 \mathrm{~kb}$ upstream of the start site of transcription and contains a glucocorticoid response element (GRE) and binding sites for liver-specific transcription factors (Jantzen et al. 1987; Grange et al. 1991; Rigaud et al. 1991; D. Nitsch, unpubl.). In the cAMP responsive enhancer at $-3.6 \mathrm{~kb}$, we have shown a binding site for hepatocyte nuclear factor 4 (HNF4; Sladek et al. 1990) to synergize with a CRE (Boshart et al.
1990; D. Nitsch, unpubl.). The third enhancer is located at $-11 \mathrm{~kb}$ and contains two domains that confer liverspecific activation, one of which is recognized by proteins of hepatocyte nuclear factor 3 (HNF3; Lai et al. 1990, 1991) family of transcription factors (Nitsch et al. 1990; D. Nitsch and G. Schütz, in prep.). Knowledge of the critical cis-regulatory elements, their cell type specificity, and the nature of the proteins binding to these sequences have now allowed us to undertake a complete analysis of the mechanism of extinction of TAT gene transcription in hepatoma/fibroblast hybrid crosses. By following the presence and activity of several liver-specific factors as well as essential components of the glucocorticoid- and cAMP-dependent signaling pathways, we show that extinction is the result of inactivation of the three enhancers of the gene and independently affects all liver-specific elements.

\section{Results}

Extinction of TAT gene activity in hepatomal fibroblast hybrid crosses is accompanied by selective loss of hepatoma-specific DNase I hypersensitive sites

To explore the basis of extinction of gene expression in somatic cell hybrids we generated hybrids between the rat hepatoma cell line FTO-2B and mouse embryo fibroblasts. Expression of the TAT gene, as well as of several other liver-specific genes, is reduced $>500$-fold in these hepatoma/fibroblast hybrid crosses in comparison with FTO-2B cells (data not shown) in agreement with a previous report (Chin and Fournier 1987). As a first step in understanding the mechanisms leading to this complete repression, we compared the chromatin structure of the TAT gene, reflected in DNase I hypersensitive sites (HSs), in extinguished hybrids and the parental hepatoma and fibroblast cells. We reasoned that loss of activators would lead to the disappearence of HSs, whereas the activity of repressor-like molecules might alter or create new HSs or have no detectable effect on their appearance. In our previous analysis of the chromatin of the TAT gene we identified several HSs located $\leqslant 18 \mathrm{~kb}$ upstream of the transcription start site, three of which correlate with liver-specific transcriptional enhancers (Fig. 1B; Becker et al. 1984; Jantzen et al. 1987; Nitsch et al. 1990; Weih et al. 1990).

Nuclei of hybrid cells were prepared and incubated with increasing amounts of DNase I, and the cleavage pattern was compared with that of DNase I-treated nuclei from fibroblasts and hepatoma cells. Figure 1A shows the results obtained with two indirect end-labeling strategies that detect the HSs located at $-18,-16$ and $-11 \mathrm{~kb}$ (left) and those distributed between -9 and $+5 \mathrm{~kb}$ with respect to the start site of transcription (right). In hepatoma/fibroblast hybrid crosses, five of the seven hepatoma cell-specific HSs are absent (HSs P, $-2.5,-3.6)$ or significantly reduced in complexity (HSs $-11,-5.4)$. The HSs at -1.0 and $-4.5 \mathrm{~kb}$ are present in both the hybrids and the parental hepatoma cell line but are absent in fibroblasts, and only the HSs at -18 and $-16 \mathrm{~kb}$ are observed in all three cell types. Each HS, 
Figure 1. Loss of DNase I HSs in hepatoma/fibroblast hybrid crosses correlates with extinction of TAT gene activity. $(A)$ Cells were induced with $10^{-6} \mathrm{M}$ dexamethasone; subsequently nuclei were isolated and incubated with increasing amounts of DNase I. DNA was digested with ApaI (left) or ScaI (right), separated on $0.6 \%$ (left) or $1.0 \%$ (right) agarose gels, and blotted. Filters were indirectly end-labeled to the ApaI site at $-8591 \mathrm{bp}$ (left) or the ScaI site at -9383 bp (right) in the TAT upstream region. DNase I HSs are indicated by arrows or a bracket and named according to the approximate position relative to the transcription start site; (P) HS at promoter. The hepatoma and fibroblast samples correspond to those presented in Nitsch et al. (1990). (B) Summary of DNase I HSs (vertical arrows) and control regions in the $5^{\prime}$ flanking sequence of the rat TAT gene. The start site and direction of transcription and the restriction sites that were indirectly end-labeled by the probe XA600 (solid box) are indicated. Regions corresponding to regulatory sequences of the TAT gene are expanded below, with individual enhancer motifs highlighted.

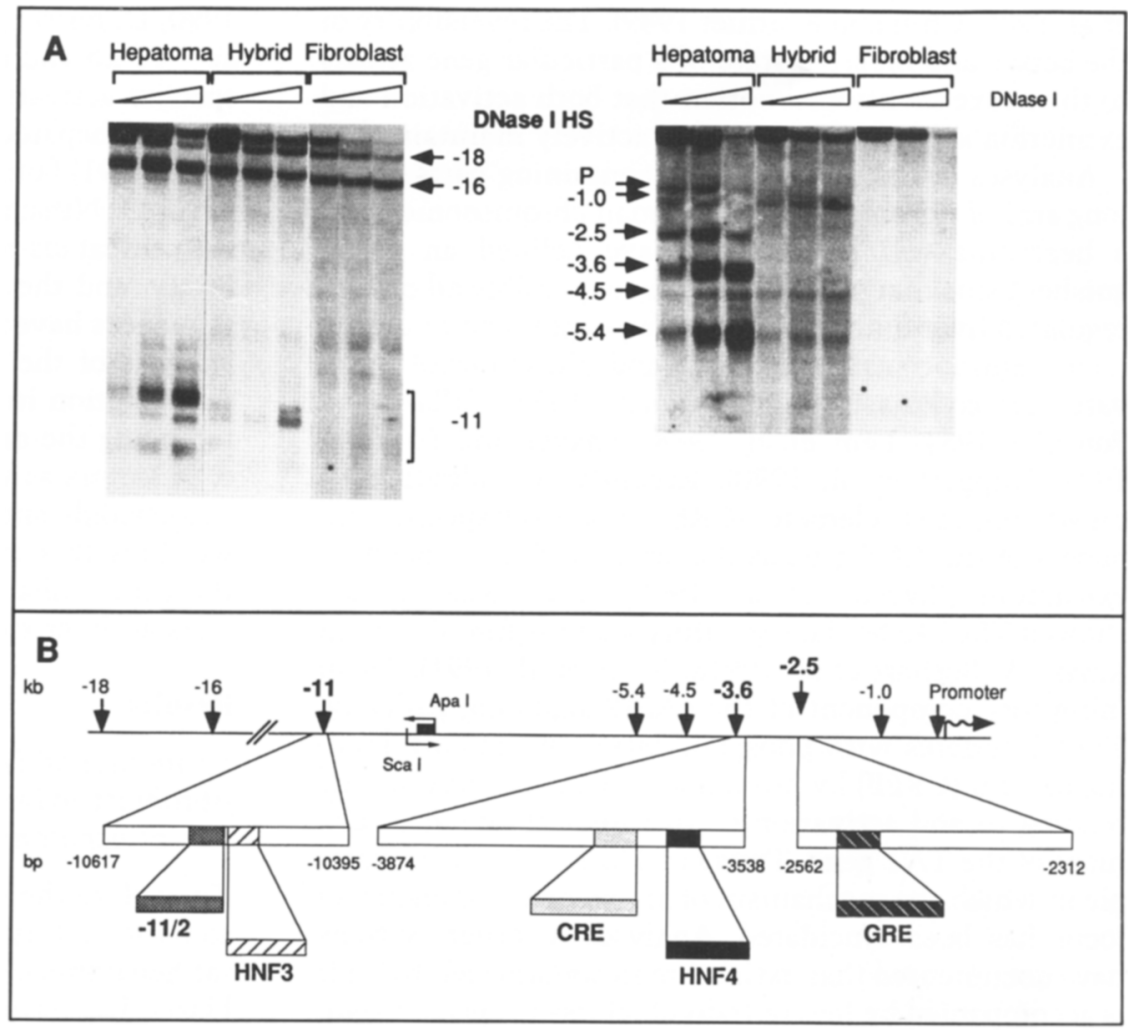

absent or reduced in the hepatoma/fibroblast hybrid crosses, corresponds to regulatory sequences of the TAT gene (Jantzen et al. 1987; Grange et al. 1989, 1991; Boshart et al. 1990; Nitsch et al. 1990; Weih et al. 1990), an observation that implies that extinction of TAT gene expression in whole-cell hybrids involves several control regions. Figure 1B depicts schematically the 5 '-flanking sequences of the TAT gene, with its HSs represented by vertical arrows. Sequences that function as transcriptional enhancers, and the important transcription factor binding sites within these enhancers, are highlighted (Jantzen et al. 1987; Boshart et al. 1990; Nitsch et al. 1990; D. Nitsch, unpubl.).

Three liver-specific enhancers of the TAT gene are silenced in hepatoma/fibroblast hybrid crosses

To define sequence elements of the TAT gene mediating its extinction in whole-cell hybrids, we compared the activity of its three liver-specific enhancers after transient transfection in hepatoma cells, fibroblasts, wholecell hybrids, and monochromosomal hybrids carrying fibroblast TSEl. The results of the transfection experiments in hybrids, depicted in Figure 2, were obtained in pools of several hundred hybrid colonies. Additional analyses of eight individual clones yielded consistent results (data not shown). Enhancer fragments and oligonucleotides corresponding to individual enhancer motifs (Fig. 2A) were tested in front of the herpes simplex virus (HSV) thymidine kinase (TK) promoter driving the bac- terial chloramphenicol acetyltransferase (CAT) gene. The activity of the SV40 enhancer was also determined and found to stimulate the TK promoter in all four cell lines (data not shown).

The enhancer at $-11 \mathrm{~kb}$ is located within a $221-\mathrm{bp}$ restriction fragment and has two essential domains: One contains a binding site for liver-specific proteins, which we have identified as $\mathrm{HNF} 3 \alpha, \mathrm{HNF} 3 \beta$, and HNF3 $\gamma$, and the other is a $35-b p$ element, here designated $-11 / 2$, which by itself confers liver cell-specific transcriptional activation on the heterologous TK promoter (D. Nitsch and G. Schütz, in prep.). The enhancer activities of the 221- and 35-bp fragments are reduced $\geqslant 40$-fold in hepatoma/fibroblast hybrid crosses as compared with the parental hepatoma cell line. Four copies of the HNF3-binding site stimulate the TK promoter threefold less than in hepatoma cells (Fig. 2B).

We have analyzed the activity of the cAMP-responsive enhancer at $-3.6 \mathrm{~kb}$ contained on a 336-bp fragment and of either of its two esssential domains tested as tandemerized oligonucleotides. Whereas TSE 1-mediated inhibition of enhancer activity can be reversed by forskolin in monochromosomal hybrids, in whole-cell hybrids the enhancer is inactive even in the presence of elevated cAMP levels (Fig. 2C). The basal transcriptional stimulation of the TK promoter by five copies of the CRE, as well as by the tandemerized HNF4 motif, is reduced $>10$-fold in hybrids (Fig. 2C). In combination, these effects lead to complete inactivity of the 336-bp enhancer fragment.

The glucocorticoid-inducible enhancer at $-2.5 \mathrm{~kb}$ of 


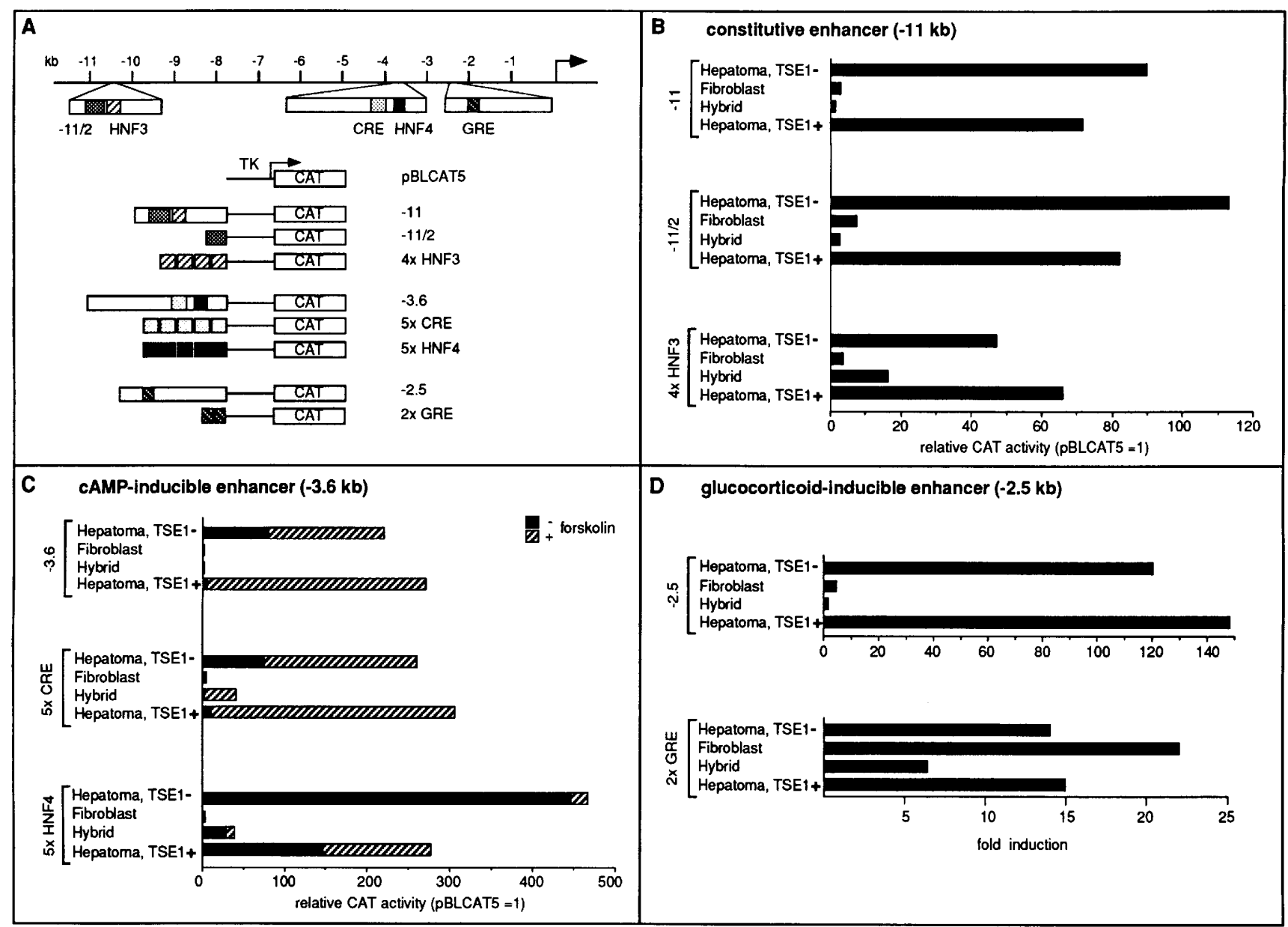

Figure 2. The activity of all three enhancers of the TAT gene is abolished in hepatoma/fibroblast hybrid crosses. Four different cell lines (hepatoma, fibroblast, hepatoma/fibroblast hybrid crosses, and a hepatoma microcell hybrid containing the TSE1 locus from human fibroblast chromosome 17) were transfected with constructs containing regulatory elements of the TAT gene, cloned in front of the HSV TK promoter, driving the bacterial CAT gene. The different cell lines were electroporated, and extracts were prepared after $48 \mathrm{hr}$ and assayed for CAT activity. All values have been corrected for variation in transfection efficiency by the expression of a cotransfected internal standard, Rous sarcoma virus long terminal repeat (RSV-LTR)-driven luciferase. The results of representative experiments are shown, which have been performed at least three times. $(A)$ The $5^{\prime}$-flanking region of the rat TAT gene is depicted with the three enhancers enlarged. The major transcription factor-binding sites within these enhancers are indicated by hatched or shaded boxes. The various constructs that were used in the transfection experiments are illustrated below. $(B)$ Analysis of constructs containing sequences from the constitutive enhancer at $-11 \mathrm{~kb}$. The bars represent the relative stimulation of the TK promoter (pBLCAT5), whose activity was set to $1 .(C)$ Analysis of constructs containing sequences from the cAMP-responsive enhancer at -3.6 $\mathrm{kb}$. After transfection, cells were split onto two separate dishes and, after $24 \mathrm{hr}$, either mock induced with $0.1 \%$ ethanol or induced with $10 \mu \mathrm{M}$ forskolin. The activity of the uninduced TK promoter was set to 1 . Uninduced values are represented by solid bars; the increase in CAT activity after forskolin induction is depicted as a hatched bar. $(D)$ Analysis of constructs containing sequences from the glucocorticoid-inducible enhancer at $-2.5 \mathrm{~kb}$. Cells were split onto two dishes after electroporation, mock induced by $0.1 \%$ ethanol, or induced by $3 \times 10^{-7} \mathrm{M}$ dexamethasone. Fold induction is given as solid bars.

the TAT gene, contained on a 250 -bp fragment, confers $>100$-fold inducibility on the TK promoter in hepatoma cells. In hybrids, as in fibroblasts, this hormone-dependent activity is very low (Fig. 2D). In contrast, the hormone-dependent stimulation by two copies of the 15-bp GRE from the enhancer is only slightly reduced in hybrids as compared with hepatoma cells (Fig. 2D). This observation leads to the conclusion that the activity of the glucocorticoid receptor is not significantly affected in hybrids, but that the liver-specific components of the enhancer are affected.
Thus, the three enhancers that contribute to liver-specific and hormone-inducible expression of the TAT gene are silenced in hepatoma/fibroblast hybrid crosses, indicating that extinction operates at multiple cis-acting elements. Moreover, in the enhancers at -11 and $-3.6 \mathrm{~kb}$, at least two enhancer motifs are independently involved.

The CRE at $-3.6 \mathrm{~kb}$ is the only direct target for TSE1 in the TAT gene

To assess whether TSE1 affects any other regulatory elements of the TAT gene in addition to the CRE of the 
enhancer at $-3.6 \mathrm{~kb}$, we transfected the constructs depicted in Figure $2 \mathrm{~A}$ into a hepatoma microcell hybrid that contains the fibroblast-derived human TSEl locus (Lem et al. 1988; Leach et al. 1989). The $-11 \mathrm{~kb}$ enhancer, as well as its two subdomains $(-11 / 2$ and the HNF3-binding site), show comparable activities in the absence or presence of the fibroblast TSE1 locus (Fig. 2B). The activity of five copies of the HNF4-binding site from the enhancer at $-3.6 \mathrm{~kb}$ is reduced two- to threefold in the presence of TSE1, which might reflect a secondary effect of the cAMP signal transduction pathway on HNF4 expression (Fig. 2C). Finally, the induction conferred by the glucocorticoid-inducible enhancer is not affected by the presence of an active TSE1 locus (Fig. 2D). Thus, in hepatoma-fibroblast hybrids, inhibition of the TAT enhancers at $-11 \mathrm{~kb}$ and $-2.5 \mathrm{~kb}$, as well as of the HNF4 motif in the enhancer at $-3.6 \mathrm{~kb}$, is mostly independent of fibroblast TSE1, indicating that fibroblast loci in addition to TSEl are involved in complete extinction of TAT gene activity, as was postulated by Thayer and Fournier (1989).

\section{Extracts from hepatoma/fibroblast hybrid crosses lack HNF4, HNF3 $\beta$, and HNF3 $\gamma$ but not $H N F 3 \alpha$ DNA-binding activities}

We were interested in correlating the reduced enhancer activities in hepatoma/fibroblast hybrid crosses with changes in the complement of proteins interacting with the enhancer motifs. Therefore, we performed gel mobility-shift experiments, comparing nuclear extracts from hepatoma, fibroblast, and hybrid cells (Fig. 3). Extracts from hepatoma cells but not from fibroblasts give rise to two prominent protein-DNA complexes with an oligonucleotide containing the HNF3-binding site from the -11-kb enhancer, both of which are competed by 100fold molar excess of an oligonucleotide containing the HNF3-binding site from the transthyretin gene (Fig. 3, lanes 1,2,7). With the help of specific antisera (kindly provided by V. Prezioso, Rockefeller University, NY), these protein-DNA complexes can be shown to contain HNF3 $\alpha, H N F 3 \beta$, and HNF3 $\gamma$ (cf. lanes 3-6). Extracts prepared from hybrids contain HNF3 $\alpha$ DNA-binding activity in amounts comparable with the parental hepatoma cell line, but no HNF3 $\beta$ - and HNF3 $\gamma$-binding activities (lanes 8-10). Thus, the HNF3 family of liver-specific transcription factors seem to be regulated differentially in hepatoma/fibroblast hybrid crosses. Similar results were obtained with an HNF3-binding site located in the glucocorticoid-inducible TAT enhancer (data not shown).

An oligonucleotide corresponding to the liver-specific BIII element of the enhancer at $-3.6 \mathrm{~kb}$ (Boshart et al. 1990) binds several proteins in hepatoma cell extracts, one of which is identified by oligonucleotide competition and specific antiserum (kindly provided by $\mathrm{F}$.

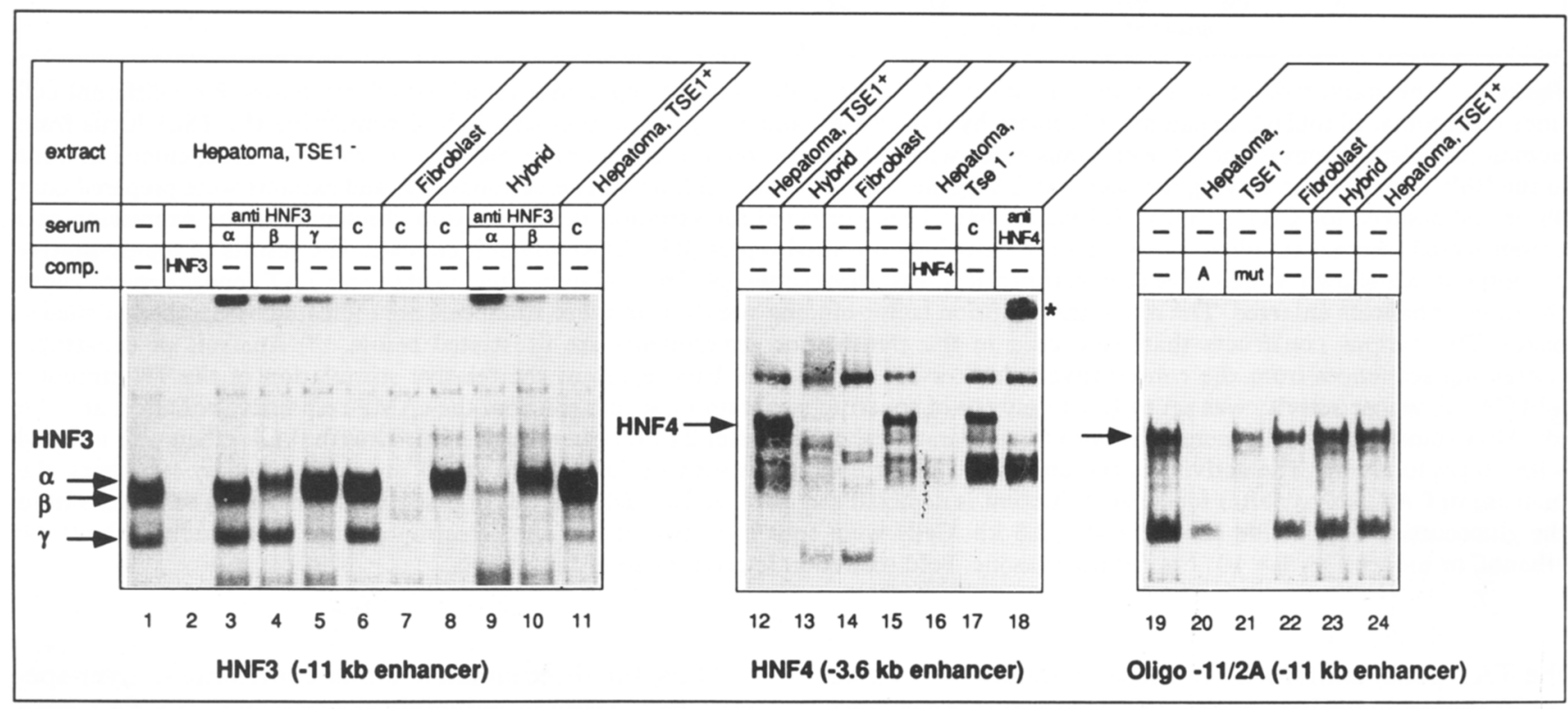

Figure 3. Nuclear extracts from hybrid cells show loss of DNA-binding activities corresponding to liver-specific transcription factors. Nuclear extracts from the cell lines indicated were incubated with labeled oligonucleotides containing the HNF3 motif from the $-11-\mathrm{kb}$ enhancer (lanes 1-11), the HNF4-binding site from the $-3.6-\mathrm{kb}$ enhancer (lanes 12-18), or motif $-11 / 2 \mathrm{~A}$ from the $-11-\mathrm{kb}$ enhancer (lanes 19-24). The protein-DNA complexes were resolved by electrophoreses in 7\% (lanes 1-18) or 4\% (lanes 19-24) polyacrylamide gels. Competition experiments were performed by preincubation of extracts with a 100 -fold molar excess of cold oligonucleotides containing the HNF3- or HNF4-binding sites from the transthyretin gene (lanes 2 and 16, respectively; Costa et al. 1989), or with oligo - 11/2A (lane 20) or a mutant of oligo -11/2A with a triple base-pair exchange (lane 21). Immunoshifts were performed by preincubation of the extracts with the antiserum (lanes 3-5,9-10,18) or as control $(\mathrm{C})$ with preimmune serum $($ lanes $6,7,8,11$ ) or $3 \%$ BSA (lane 17). Arrows point to specific protein-DNA complexes; and the asterisk indicates the supershift obtained with the HNF4 antiserum. In the presence of the HNF3 antisera we observe material that does not migrate into the gel. 
Sladek, Rockefeller University, NY) as HNF4 (Fig. 3, lanes 12-18). The HNF4 DNA-binding activity is absent in extracts from hybrids, in agreement with a report by Kuo et al. (1992). The identity of the proteins giving rise to the other retarded complexes is unclear. Competition by the HNF4 binding site indicates that these might contain related proteins (cf. Ladias et al. 1992). Some of these additional protein-DNA complexes are also not formed with hybrid cell extracts.

DNase I footprint experiments have identified two distinct DNA-binding activities in the $-11 / 2$ domain of the enhancer at $-11 \mathrm{~kb}$, both of which are found in extracts from hepatoma cells and fibroblasts (D. Nitsch and G. Schütz, in prep.). Lanes 19-24 in Figure 3 show gel mobility-shift analyses performed with oligonucleotide $-11 / 2 \mathrm{~A}$ that encompasses the $5^{\prime}$ half of the enhancer domain $-11 / 2$. The specific complex is defined by its sensitivity to a triple point mutation (Fig. 3, lanes 19-21), which also results in loss of $>90 \%$ of the activity of this enhancer domain in transient transfection experiments (D. Nitsch and G. Schütz, in prep.). The specific protein-DNA complex is also observed with extracts from fibroblasts (lane 22) and hybrids (lane 23). Similar results were obtained in gel-shift assays using an oligonucleotide encompassing the $3^{\prime}$ half of enhancer domain $-11 / 2$ (data not shown). Thus, we do not observe any differences between extracts from hepatoma and hybrid cells in the in vitro DNA-binding activities to the enhancer domain $-11 / 2$, although this region does not activate the TK promoter in hybrids (Fig. 2B).

With all three enhancer motifs, extracts from the monochromosomal hepatoma cell line containing the fibroblast-derived TSE1 locus (hepatoma, TSE ${ }^{+}$| gave rise to protein-DNA complexes comparable with those observed with the hepatoma cell line FTO-2B (Fig. 3, lanes $11,12,24)$. This is compatible with the results obtained in transient transfection experiments (see Fig. 2).

\section{mRNAs for HNF4, HNF3 $\beta$, and HNF3 $\gamma$ are not detectable in hepatoma/fibroblast hybrid crosses}

To analyze the level at which the activities of HNF4 and HNF3 $\beta$ and HNF3 $\gamma$ are affected, we performed Northern blot analyses to detect the respective mRNAs. As shown in Figure 4B, no HNF4 mRNA is detectable in hybrids and in fibroblasts. Hepatoma cells contain mRNAs for all three HNF3 proteins, whereas we detect no $\beta$ - and $\gamma$-form mRNAs but high levels of HNF3 $\alpha$ mRNA in hybrids (Fig. 4C). In fibroblasts and hybrids we observe additional bands with the HNF3 probe. Because the hybridization was performed with a probe corresponding to the conserved fork head domain of HNF3 $\alpha$, these additional mRNAs might correspond to other members of the fork head family, of which at least seven have been identified (K. Kästner and G. Schütz, unpubl.). The lack of HNF4, HNF3 3 , and HNF3 $\gamma$ DNA-binding activities, therefore, corresponds to dramatically reduced steady-state levels of their mRNAs. The Northern blot depicted in Figure $4 \mathrm{C}$ was also hybridized with a probe for the regulatory

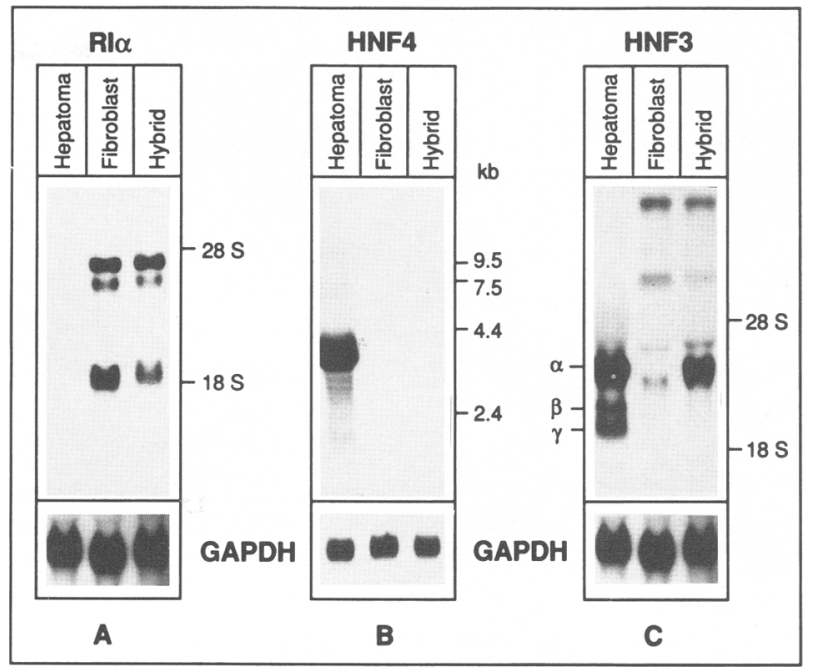

Figure 4. mRNAs coding for HNF4 and HNF3 $\beta$ and HNF3 $\gamma$, but not for HNF3 $\alpha$ are absent in hybrid cells. Total RNA (15 $\mu \mathrm{g})$ isolated from the indicated cell lines was separated in a $1 \%$ agarose gel, blotted, and hybridized in $A$ with a 40 -mer oligonucleotide complementary to a sequence $100 \%$ conserved between the rat- and mouse-coding region of the regulatory subunit RI $\alpha$ of protein kinase $A$, in $B$ with a riboprobe complementary to the HNF4 CDNA, and in $C$ with a riboprobe corresponding to the fork head domain of HNF3 $\alpha$. A and $C$ show the same Northern filter, which was hybridized successively to the RI $\alpha$ and HNF3 probes. The three RI $\alpha$ mRNAs are the result of alternative polyadenylation (Øyen et al. 1988). The sizes of the HNF3 mRNAs are described in Lai et al. (1991). Positions of the rRNAs are marked in $A$ and $C$, and in $B$ the RNA ladder from Bethesda Research Laboratories was used as size marker. The filters were rehybridized with a probe from the rat glyceraldehyde-3-phosphate-dehydrogenase cDNA /GAPDH; Fort et al. 1985) as internal standard.

subunit RI $\alpha$ of protein kinase A. As expected, RI $\alpha /$ TSE 1 mRNAs are abundant in fibroblasts and hybrids but undetectable in hepatoma cells (Fig. 4A).

Genomic footprinting reveals loss of protein binding at the $-11-\mathrm{k} b$ enhancer in hepatoma/fibroblast hybrid crosses

The identity of the proteins interacting with domain $-11 / 2$ of the constitutive enhancer at $-11 \mathrm{~kb}$ is unknown. To follow binding activities in vivo we performed genomic footprinting analyses. In Figure 5, the reactivity of the lower strand to methylation by dimethylsulfate (DMS) was compared between hepatoma and hybrid cells. In hepatoma cells prominent protections and enhancements are observed in the enhancer domain $-11 / 2$ and at the HNF3-binding site. The DMS reactivity of the hybrid cells is comparable with that of fibroblasts and of protein-free hepatoma DNA (data not shown). Although proteins interacting with these enhancer motifs in vitro are found in extracts from both cell types, in vivo the respective binding sites are occupied only in hepatoma cells. The absence of in vivo pro- 


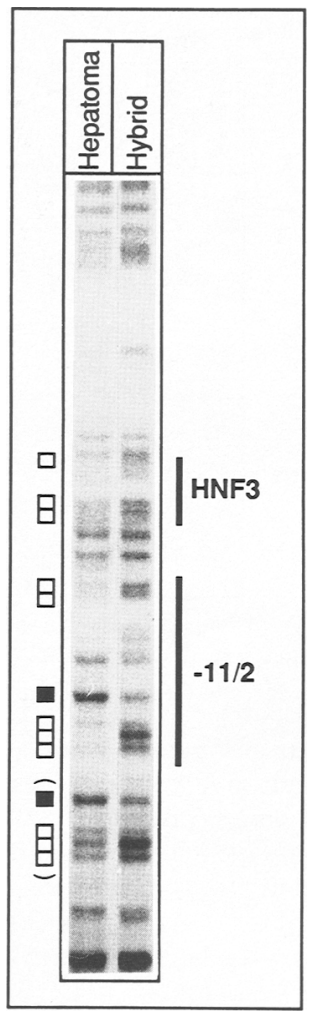

Figure 5. Genomic footprinting at the enhancer at $-11 \mathrm{~kb}$ reveals absence of protein binding in hepatoma/fibroblast hybrid crosses. The DMS reactivity of the lower strand of the TAT gene enhancer at $-11 \mathrm{~kb}$ was analyzed in hepatoma and hybrid cells as detailed in Materials and methods. Guanosine residues that show an altered reactivity in hepatoma cells, as compared with hybrids, are marked by $\square$ (protections) or $\square$ (enhancements) at left. Sequences corresponding to the two essential enhancer domains are indicated by vertical lines at right. The genomic DNA of the H4IIEC3-derived hepatoma cell line FTO$2 \mathrm{~B}$ contains a 16 -bp duplication within region $-11 / 2$ when compared with rat DNA of other sources. Therefore, a control lane with DNA from DMS-treated rat fibroblasts cannot be directly aligned and has been omitted. Protections and enhancements within the duplicated sequence are bracketed. The hybrid lane was exposed twice as long as the hepatoma lane to compensate for the reduction in signal, which is the result of the dilution by the mouse genomic DNA in the hybrid samples.

tein binding in hybrid cells correlates with loss of or reduced activity of the corresponding enhancer domains in transient transfection experiments in these cells (Fig. 2B).

\section{Discussion}

This study was undertaken to define the molecular mechanisms underlying extinction of gene activity in somatic cell hybrids. Possible mechanisms of extinction include inhibition of the synthesis of transcription factors that determine cell-specific expression or interference with the binding to the recognition sequence or with the transcriptional stimulatory activity of these factors. The action of dominant repressor-like molecules, which might bind to specific silencer elements or compete for binding with an activator, could also be envisaged. Extinction of TAT gene activity in whole-cell hybrids is accompanied by the loss of DNase I HSs. This argues against a role of negative regulatory elements, as binding of repressors or silencers might be expected to result in changes in chromatin structure, giving rise to altered or new DNase I HSs, or both.

We anticipated that no single mechanism, dependent on only one extinguisher locus, such as TSE1, would be likely to explain extinction of TAT gene transcription in whole-cell hybrids. In these hybrids the TAT gene is shut off by at least three orders of magnitude and is not inducible by hormones, whereas in monochromosomal hybrids carrying an active TSE1 locus, the maximally 20-fold reduction of TAT gene activity can be reversed by cAMP administration. Moreover, examination of the chromatin structure of the TAT gene revealed significant changes in whole-cell hybrids, with loss of several DNase I HSs corresponding to regulatory sequences (Fig. 1). In contrast, in monochromosomal hybrids, only subtle changes are observed at the DNase I HS at the promoter (Nitsch et al. 1990). The experiments described here clearly establish that extinction in whole-cell hybrids has a polygenic basis affecting the activity of all three enhancers that determine liver-specific and hormone-dependent expression of the TAT gene. The activity and synthesis of several factors interacting with these enhancers are altered in hybrids. Our analyses also establish that the CRE in the CAMP responsive enhancer at $-3.6 \mathrm{~kb}$ is the only direct target in the TAT gene influenced by the presence of the fibroblast TSE1 locus.

DNA-binding (Weih et al. 1990; Nichols et al. 1992) and transcriptional activity (Gonzales and Montminy 1989) of CREB are influenced by its state of phosphorylation by protein kinase A. TSEl is identical with the regulatory subunit RI $\alpha$ of protein kinase $A$ and its expression is low in liver and hepatoma cells but high in fibroblasts and hybrids (Fig. 4A; Boshart et al. 1991a). Therefore, TSE1/RI $\alpha$ interferes with phosphorylation of CREB in hepatoma/fibroblast hybrid crosses, and leads to reduced binding and transcriptional activity of CREB. In these hybrids, the activity of a multimerized HNF4binding site is also significantly reduced (Fig. $2 \mathrm{C}$ ) and this correlates with the loss of protein-DNA binding activities to this enhancer motif in hybrids owing to inhibition of HNF4 gene expression (Fig. 4B; Kuo et al. 1992). The HNF4 shift represents the only prominent DNAbinding activity observed in liver; moreover, the contacts resulting from DMS interference studies are as expected from the mutational analysis (Boshart et al. 1990; data not shown). Because the HNF4 element acts interdependently with the CRE, the other essential element of this enhancer, the lack of HNF4, and the lowered activity of CREB lead to complete loss of enhancer activity as well as to lack of inducibility by cAMP. This correlates with loss of the respective DNase I HS in complete somatic cell hybrids (Fig. 1). In contrast, in the TSE1- 
containing microcell hybrids this DNase I HS is present (Nitsch et al. 1990).

The glucocorticoid-inducible enhancer of the TAT gene contains several binding sites for liver-specific factors, including C/EBP (Grange et al. 1991; Rigaud et al. 1991) and HNF3 (D. Nitsch, unpubl.), in the vicinity of its GRE. It has been demonstrated that a single GRE requires complementation by another transcription factor-binding site to activate transcription from a promoter distal position (Strähle et al. 1988). As the glucocorticoid receptor is active in many or possibly all cell types, it is not surprising that a tandem dimer of the 15-bp GRE in front of the TK promoter is inducible in hepatoma and hybrid cells. Steady-state mRNA levels for the glucocorticoid receptor are comparable in these cells (A. Reik and G. Schütz, unpubl.). In contrast, the inducibility of the TAT enhancer at $-2.5 \mathrm{~kb}$ is lost in hepatoma/fibroblast hybrid crosses (Fig. 2D), correlating with the absence of the corresponding hormone-inducible DNase I HS (Fig. 1). This may relate to the absence of HNF3 proteins. HNF $3 \beta$ and HNF3 $\gamma$ DNA-binding activities and mRNAs are absent in hybrids, but HNF3 $\alpha$ is present (Figs. 3 and $4 \mathrm{C}$ ), suggesting different regulatory functions of the three proteins. The differential regulation of the HNF3 proteins in hybrids might indicate a more general coordinate regulation of HNF3 $\beta$ and HNF3 $\gamma$ independent of HNF3 $\alpha$. We did not observe any difference in DNA-binding activities to the C/EBP site (data not shown). Although C/EBP (LAP; Descombes et al. 1990; Poli et al. 1990) was contained in extracts from all four cell lines, $\mathrm{C} / \mathrm{EBP} \alpha$ could not be detected in any and has been reported previously to be expressed at very low levels in hepatoma cell lines (Friedman et al. 1989).

In the constitutive liver-specific enhancer at $-11 \mathrm{~kb}$, at least two essential components, the HNF3-binding site and the $-11 / 2$ domain, are affected in extinguished hybrids (Fig. 2B). Although HNF3 $\alpha$ is present in hybrids (Figs. 3 and 4) and possibly leads to some activation of a construct containing four tandemerized HNF3-binding sites in transient transfection experiments, we do not observe protein binding to this HNF3 motif in vivo (Fig. 5). Similarly, in vitro DNA-binding studies have identified ubiquitous proteins binding to the liver-specific enhancer domain $-11 / 2$, which in hybrids does not, however, interact with proteins in vivo, as revealed by genomic footprinting experiments (cf. Figs. 3 and 5). Although it cannot be excluded that the relevant liverenriched proteins have not been identified in the in vitro protein-DNA binding studies, these results extend previous observations of cell type-specific in vivo DNA binding of ubiquitously expressed factors (Becker et al. 1987). As has been shown for CREB (Weih et al. 1990; Nichols et al. 1992), protein modification might also be involved in restricting the interaction of the ubiquitous factors with enhancer domain $-11 / 2$ in vivo.

The major conclusion drawn from this work and previous analyses of individual cell type-specific factors in several hybrid systems (McCormick et al. 1988; Cereghini et al. 1990; Baumhueter et al. 1990; Bergman et al. 1990; Junker et al. 1990) is that extinction of gene activity is attributed to lack of activation. This may be the result of reduced synthesis of factors or modulation of their activity by post-translational modification, such as occurs in TSE1-mediated extinction. Here, we have documented this rule for five distinct regulatory elements organized in three enhancers controlling the liverspecific expression of one particular gene. In hepatoma/ fibroblast hybrid crosses, the combined effects of the multiple regulatory events result in extinction of TAT gene activity by three orders of magnitude, as well as in loss of hormone inducibility. Recently, overexpression of HNF4 in dedifferentiated hepatoma lines has been shown to relieve inhibition of HNFl $\alpha$ gene activity (Kuo et al. 1992). However, because of the combinatorial nature of the control of TAT gene activity and the dominant nature of TSEl, we anticipate that overexpression of any one of the factors important for TAT gene activity will not reverse its extinction in whole-cell hybrids. Also, overexpression of a combination of factors will not lead to reversal of extinction, as the genes coding for the proteins that bind to the -11 enhancer cannot be complemented. In line with this, the expression of the $\alpha_{1}$ antitrypsin and immunoglobulin genes could not be restored in somatic cell hybrids by overexpression of their important transcriptional activators HNF1 $\alpha$ and Oct-2, respectively (Junker et al. 1990; Bulla et al. 1992; P. Matthias, pers. comm.). Extinction of the albumin gene has also been related to loss of HNFl $\alpha$ /Cereghini et al. 1988, 1990). However, HNFl $\alpha$ expression is independent of TSE2, which was defined as a negative regulator of albumin expression in microcell hybrids retaining chromosome 1 (Chin and Fournier 1989; Gourdeau et al. 1989). This implies that extinction of albumin gene expression also involves more than one independent locus, similarly to that shown for the TAT gene.

With the exception of the glucocorticoid receptor, all transcription factors determined thus far to be important for TAT gene expression are absent or inactive in hepatoma/fibroblast hybrid crosses. This could either imply the existence of as many extinguisher loci as cell typespecific transcription factors or, more likely, the activity of few putative master regulators controlling the expression of several of these factors. This may reflect a hierarchical order in the expression of cell-specific transcription factors. Such a hierarchy has already been seen in the control of HNFl $\alpha$ by HNF4 (Tian and Schibler 1991; Kuo et al. 1992) and may be a more frequent occurrence, similar to the transcription factor cascades involved in Drosophila development (for review, see Lipshitz 1992). HNF3 proteins have a conserved DNA-binding domain with a high degree of homology to the Drosophila protein fork head, which is dependent on expression of the gene tailless (Weigel et al. 1989; Weigel and Jäckle 1990). A potential mammalian homolog of the tailless gene could therefore be upstream of the HNF3 proteins in a hypothetical cascade.

Whereas extinction of cell type-specific gene expression in somatic cell hybrids largely results from lack of activation, the mechanisms that control the expression of the corresponding tissue-specific extinguisher loci re- 
main to be elucidated. Analyses of the regulatory elements of important cell type-specific transcription factors have revealed that autoregulatory loops play an important role in establishment and maintenance of the differentiated state (for review, see Blau 1992). The work in somatic cell hybrids establishes that dominant-negative control of cell type-specific functions by the tissuespecific extingusher loci TSE 1 and TSE2 identified so far, is stably inherited in cis and not subject to regulation by trans-acting factors (for further discussion, see Gourdeau and Fournier 1990; Boshart et al. 1991a). Similar mechanisms of control are likely to act also on the putative master regulators that participate in the determination of a particular cell fate.

\section{Materials and methods}

\section{Plasmid constructions}

Synthetic oligonucleotides used for cloning and in gel-retardation experiments were synthesized on an Applied Biosystems synthesizer. Unless mentioned otherwise, all constructs used in the transfection experiments are based on the plasmid pBLCAT5, which contains 105 bp of the HSV TK promoter driving the bacterial CAT gene (Boshart et al. 1991b). Construct -11 contains a restriction fragment corresponding to sequences from -10616 to $-10395 \mathrm{bp}$ with respect to the start site of transcription cloned into the HincII site in the polylinker of pBLCAT5. In construct $-11 / 2$ an oligonucleotide-containing sequences from -10548 to -10515 bp $\left(5^{\prime}\right.$-GATCCACGCAATCAGTGGCAATAGTGAAGTCACTGAGCCA-3') is cloned in the sense orientation into the BamHI site of pBLCAT5. In the $4 \times$ HNF3 construct, four copies of an oligonucleotide containing sequences from - 10513 to -10483 bp $\left(5^{\prime}\right.$-GATCCGACGTTTCTCAATATTTGCTCTGGCAGATA-3') are cloned head to tail in the sense orientation into the BamHI site. The constructs containing sequences from the enhancer at $-3.6 \mathrm{~kb}$ are described in Ruppert et al. (1990). The constructs with sequences from the glucocorticoid-inducible enhancer contain a restriction fragment from -2562 to -2312 bp or two copies of a 15-bp oligonucleotide corresponding to GRE II from the TAT enhancer (Strähle et al. 1987) and are cloned in the polylinker upstream of the TK promoter in pBLCAT2 (Luckow and Schütz 1987). All constructs containing synthetic oligonucleotides were sequenced by the method of Chen and Seeburg (1985).

\section{Cell culture and transfections}

Cultures of the various cell lines, transfections, and CAT assays were performed as described in Boshart et al. (1990). Hepatomafibroblast hybrids were obtained by polyethylene glycol (PEG) fusion between FTO-2B hepatoma cells [ $\mathrm{TK}^{-}$, ouabain sensitive (Killary et al. 1984; Killary and Fournier 1984)| and mouse embryo fibroblasts $\left[\mathrm{TK}^{+}\right.$, ouabain resistant la kind gift of Dr. J. Schlehofer, German Cancer Research Center)] and selection in HAT/ouabain medium $(0.1 \mathrm{mM}$ hypoxanthine, $0.4 \mu \mathrm{M}$ aminopterin, $20 \mu \mathrm{M}$ thymidine, and $3 \mathrm{mM}$ ouabain) for 2 weeks. More than 200 hybrid colonies were pooled and frozen in aliquots. For transfections and preparation of nuclei or protein extracts, aliquots were freshly thawed and cultured in HAT medium. Hybrids were electroporated, as described in Boshart et al. (1990), using $5 \times 10^{6}$ cells. The TSE $1^{+}$microcell hybrid cell line 7AE27 is described in Leach et al. (1989) and contains parts of the human fibroblast chromosome 17, including the TSE1/RI $\alpha$ lo- cus. Cells were harvested $48 \mathrm{hr}$ after gene transfer. A luciferase expression vector was cotransfected as internal reference [Rous sarcoma virus (RSV)-driven luciferase; Boshart et al. 1990], and the luciferase assay was performed as described by de Wet et al. (1987).

\section{DNase I HS mapping}

Preparation of nuclei, DNase I digestions, and indirect end-labeling were performed as described elsewhere (Becker et al. 1984; Jantzen et al. 1987), using the following DNase I concentrations: hepatoma cell nuclei $120,200,300 \mathrm{U} / \mathrm{ml}$, hybrid nuclei $360,600,800 \mathrm{U} / \mathrm{ml}$, and fibroblast nuclei $500,900,1600$ $\mathrm{U} / \mathrm{ml}$. The probe was transcribed from pXA600, which is described in Nitsch et al. (1990).

\section{Nuclear extract preparation and gel mobility-shift assays}

Nuclear extracts used in gel-shift assays with oligonucleotide $-11 / 2$ A were prepared as described by Dignam et al. (1983), with modifications (Wildeman et al. 1984). For gel shift experiments with the HNF3- and HNF4-binding sites, nuclear extracts prepared according to Schreiber et al. (1989) were used. In gel shift assays with oligonucleotide - 11/2A (5'-GATCTGCCGTGAGACACGCAATCAGTGGCG-3') $7.5 \mu \mathrm{g}$ of protein was incubated for $10 \mathrm{~min}$ on ice with 10 fmoles of labeled oligonucleotide in the presence of $500 \mathrm{ng}$ of poly[d(A-T)] in $10 \mathrm{mM}$ HEPES (pH 7.9), $70 \mathrm{~mm} \mathrm{KCl}, 6 \mathrm{~mm} \mathrm{MgCl} 2,4 \mathrm{~mm}$ spermidine, $10 \%$ glycerol, and $0.5 \mathrm{~mm}$ DDT. Protein-DNA complexes were separated in $4 \%$ polyacrylamide gels at $15 \mathrm{~V} / \mathrm{cm}$ in $0.5 \times \mathrm{TBE}$ buffer. In gel-shift assays with the HNF3-binding site (5'-GATCCGACGTTTCTCAATATTTGCTCTGGCAGATA-3') and the HNF4-binding site $\left(5^{\prime}\right.$-GATCTCTGCTGCTCTTTGATCTGTATACCG-3'), $5 \mu \mathrm{g}$ of extract was preincubated for $10 \mathrm{~min}$ on ice with $500 \mathrm{ng}$ of poly[d(I-C)] in $20 \mathrm{~mm}$ HEPES $(\mathrm{pH} 7.9), 4 \%$ Ficoll, $2 \mathrm{~mm} \mathrm{MgCl} 2,40 \mathrm{mM} \mathrm{KCl}, 0.1 \mathrm{~mm}$ EGTA (pH 8), and 0.5 mM DTT. After the addition of 10 fmoles of labeled oligonucleotide and incubation for $10 \mathrm{~min}$ on ice, the protein-DNA complexes were separated on $7 \%$ polyacryamide gels at $15 \mathrm{~V} / \mathrm{cm}$ in $0.3 \times$ TBE. Specific antisera directed against HNF4 (Sladek et al. 1990) and HNF3 $\alpha$, HNF3 $\beta$, or HNF3 (Lai et al. 1990, 1991) were kindly provided by F. Sladek and V. Prezioso (Rockefeller University, NY), respectively.

\section{RNA analyses}

Total RNA was extracted by the guanidinium isothiocyanate/ $\mathrm{CsCl}$ cushion method. Northern blot analysis was performed as described in Boshart et al. (1991a). The RI $\alpha$ oligonucleotide probe is described in the legend to Figure $2 \mathrm{C}$ of Boshart et al. (1991a) and was used as indicated there. The HNF3 riboprobe was transcribed from a Bluescript vector containing a 300-bp polymerase chain reaction (PCR) fragment encompassing the fork head domain of the mouse HNF3 $\alpha$ gene (kindly provided by H. Hiemisch, German Cancer Research Center). The HNF4 riboprobe was transcribed from a Bluescipt(KS) vector (kindly provided by S. Taraviras, German Cancer Research Center) containing the rat HNF4 cDNA (Sladek et al. 1990; a kind gift of J. Darnell, German Cancer Research Center). Both riboprobes were hybridized at $70^{\circ} \mathrm{C}$ and washed off at $70^{\circ} \mathrm{C}$ to $75^{\circ} \mathrm{C}$ for $3 \times 10 \mathrm{~min}$ in the solutions given in Boshart et al. (1991a).

\section{Genomic footprinting}

Methylation of intact cells and of protein-free DNA, purification of the DNA, and cleavage with piperidine were performed 
as described in Becker and Schütz (1988). Twenty-five micrograms of piperidine-cleaved DNA was subjected to a linear amplification reaction as described in Reik et al. (1991), using a primer corresponding to the upper strand of the TAT sequences from -10718 to $-10693 \mathrm{bp}$. Amplifications were performed with 10 units of Taq polymerase (Perkin-Elmer) in 30 cycles with 1 min denaturation at $92^{\circ} \mathrm{C}, 1$-min annealing at $64^{\circ} \mathrm{C}$, and elongation for $1.7 \mathrm{~min}$ at $72^{\circ} \mathrm{C}$. The purified DNAs were subsequently analyzed on a $6 \%$ sequencing gel, electroblotted onto GeneScreen, baked at $80^{\circ} \mathrm{C}$, covalently cross-linked by UV irradiation, and hybridized as described in Becker and Schütz (1988), using a cDNA probe of high specific activity (Weih et al. 1988) that corresponds to TAT sequences from - 10562 to $-10677 \mathrm{bp}$.

\section{Acknowledgments}

We thank J. Darnell, V. Prezioso, and F. Sladek for generous gifts of HNF3 and HNF4 antibodies, J. Schlehofer for kindly supplying mouse embryo fibroblasts, and D. Rudolph for performing transfections in hybrid clones. We are grateful to G. Kelsey and F. Stewart for critical reading of the manuscript, C. Schneider for secretarial assistance, and W. Fleischer for oligonucleotide synthesis and photography. This work was supported by the Deutsche Forschungsgemeinschaft through SFB 229, the Leibniz Programm, and the Fonds der Chemischen Industrie.

The publication costs of this article were defrayed in part by payment of page charges. This article must therefore be hereby marked "advertisement" in accordance with 18 USC section 1734 solely to indicate this fact.

\section{References}

Baumhueter, S., G. Courtois, and G.R. Crabtree. 1988. A variant nuclear protein in dedifferentiated hepatoma cells binds to the same functional sequences in the $\beta$-fibrinogen gene promoter as HNF-1. EMBO I. 7: 2485-2493.

Baumhueter, S., D.B. Mendel, P.B. Conley, C.J. Kuo, Ch. Turk, M.K. Graves, C.A. Edwards, G. Courtois, and G.R. Crabtree. 1990. HNF-1 shares three sequence motifs with the POU domain proteins and is identical to LF-B1 and APF. Genes \& Dev. 4: 372-379.

Becker, P.B., and G. Schütz. 1988. Genomic footprinting. In $\mathrm{Ge}$ netic engineering, principles and methods (ed. J.K. Setlow), vol. 10, pp. 1-19. Plenum Press, New York.

Becker, P.B., R. Renkawitz, and G. Schütz. 1984. Tissue-specific DNaseI-hypersensitive sites in the $5^{\prime}$-flanking sequences of the tryptophan oxygenase and the tyrosine aminotransferase genes. EMBO I. 3: 2015-2020.

Becker, P.B., S. Ruppert, and G. Schütz. 1987. Genomic footprinting reveals cell type-specific DNA binding of ubiquitous factors. Cell 51: 435-443.

Bergman, Y., B. Strich, H. Sharir, R. Ber, and R. Laskov. 1990. Extinction of Ig gene expression in myeloma $\times$ fibroblast somatic cell hybrids is accompanied by repression of the oct- 2 gene encoding a B-cell specific transcription factor. $E M B O F$. 9: 849-855.

Blau, H.M. 1992. Differentiation requires continous active control. Annu. Rev. Biochem. 61: 1213-1230.

Boshart, M., F. Weih, A. Schmidt, R.E.K. Fournier, and G. Schütz. 1990. A cyclic AMP response element mediates repression of tyrosine amino transferase gene expression by the tissue-specific extinguisher locus Tse-1. Cell 61: 905916.
Boshart, M., F. Weih, M. Nichols, and G. Schütz. 1991a. The tissue-specific extinguisher locus TSE1 encodes a regulatory subunit of cAMP-dependent protein kinase. Cell 66: 849859.

Boshart, M., M. Klüppel, A. Schmidt, G. Schütz and B. Luckow. 1991b. Reporter constructs with low background activity utilizing the cat gene. Gene 110: 129-130.

Bulla, G.A., V. DeSimone, R. Cortese, and R.E.K. Fournier. 1992. Extinction of $\alpha 1$-antitrypsin gene expression in somatic cell hybrids: Evidence for multiple controls. Genes \& Dev. 6: 316-327.

Cereghini, S., M. Blumenfeld, and M. Yaniv. 1988. A liver-specific factor essential for albumin transcription differs between differentiated and dedifferentiated rat hepatoma cells. Genes \& Dev. 2: 957-974.

Cereghini, S., M. Yaniv, and R. Cortese. 1990. Hepatocyte dedifferentiation and extinction is accompanied by a block in the synthesis of mRNA coding for the transcription factor HNF1/LFB1. EMBO I. 9: 2257-2263.

Chen, E.Y. and P.H. Seeburg. 1985. Supercoil sequencing: A fast and simple method for sequencing plasmid DNA. DNA 4: 165-170.

Chin, A.C. and R.E.K. Fournier. 1987. A genetic analysis of extinction: Trans-regulation of 16 liver-specific genes in hepatoma-fibroblast hybrid cells. Proc. Natl. Acad. Sci. 84: 1614-1618.

- 1989. Tse-2: A trans dominant extinguisher of albumin gene expression in hepatoma hybrid cells. Mol. Cell. Biol. 9: $3736-3743$.

Costa, R.H., D.R. Grayson, and J.E. Darnell. 1989. Multiple hepatocyte-enriched nuclear factors function in the regulation of transthyretin and $\alpha 1$-antitrypsin genes. Mol. Cell. Biol. 9: $1415-1425$.

Davidson, R.L. 1974. Gene expression in somatic cell hybrids. Annu. Rev. Genet. 8: 195-218.

Descombes, P.M. M. Chojkier, S. Lichtsteiner, E. Falvey, and U. Schibler. 1990. LAP, a novel member of the C/EBP gene family, encodes a liver-enriched transcriptional activator protein. Genes \& Dev. 4: 1541-1551.

de Wet, J.R., K.V. Wood, M. DeLuca, D.R. Helinski, and S. Subramani. 1987. Firefly luciferase gene: Structure and expression in mammalian cells. Mol. Cell. Biol. 7: 725-737.

Dignam, J.D., R.M. Lebovitz, and R.G. Roeder. 1983. Accurate transcription initiation by RNA polymerase II in a soluble extract from isolated mammalian nuclei. Nucleic Acids Res. 11: 1475-1489.

Fort, P., L. Marty, M. Piechaczyk, S. El Sabrouty, C. Dani, P. Jeanteur, and J.M. Blanchard. 1985. Various rat adult tissues express only one major mRNA species from the glyceraldehyde-3-phosphate dehydrogenase multigenic family. $\mathrm{Nu}$ cleic Acids Res. 13: 1431-1442.

Friedman, A.D., W.H. Landschulz, and S.L. McKnight. 1989. CCAAT/enhancer binding protein activates the promoter of the serum albumin gene in cultured hepatoma cells. Genes \& Dev. 3: 1314-1322.

Gonzalez, G.A. and M.R. Montminy. 1989. Cyclic AMP stimulates somatostatin gene transcription by phosphorylation of CREB at serine 133. Cell 59: 675-680.

Gourdeau, H. and R.E.K. Fournier. 1990. Genetic analysis of mammalian cell differentiation. Annu. Rev. Cell Biol. 6: 6994.

Gourdeau, H., T.C. Peterson, and R.E.K. Fournier. 1989. Differential activity of a tissue-specific extinguisher locus in hepatic and nonhepatic cells. Mol. Cell. Biol. 9: 1813-1822.

Grange, T., J. Roux, G. Rigaud, and R. Pictet. 1989. Two remote glucocorticoid responsive units interact cooperatively to 
promote glucocorticoid induction of rat tyrosine aminotransferase gene expression. Nucleic Acids Res. 17: 86958709.

- 1991. Cell-type-specific activity of two glucocorticoid responsive units of rat tyrosine aminotransferase gene is associated with multiple binding sites for C/EBP and a novel liver-specific nuclear factor. Nucleic Acids Res. 19: 131139.

Jantzen, H.-M., U. Strähle, B. Gloss, F. Stewart, W. Schmid, M. Boshart, R. Miksicek, and G. Schütz. 1987. Cooperativity of glucocorticoid response elements located far upstream of the tyrosine aminotransferase gene. Cell 49: 29-38.

Jones, K.W., M.H. Shapero, M. Chevrette, and R.E.K. Fournier. 1991. Subtractive hybridisation cloning of a tissue-specific extinguisher: TSEl encodes a regulatory subunit of protein kinase A. Cell 66: 861-872.

Junker, S., S. Pedersen, E. Schreiber, and P. Matthias. 1990. Extinction of an immunoglobulin $\mathrm{k}$ promoter in cell hybrids is mediated by the octamer motif and correlates with suppression of Oct-2 expression. Cell 61: 467-474.

Killary, A.M. and R.E.K. Fournier. 1984. A genetic analysis of extinction: Trans-dominant loci regulate expression of liverspecific traits in hepatoma hybrid cells. Cell 38: 523-534.

Killary, A.M., T.G. Lugo, and R.E.K. Fournier. 1984. Isolation of thymidine kinase deficient rat hepatoma cells by selection with bromo-deoxyuridine, Hoechst 33258, and visible light. Biochem. Genet. 22: 201-213.

Kuo, C.J., P.B. Conley, L. Chen, F.M. Sladek, J.E. Darnell Jr., and G.R. Crabtree. 1992. A transcriptional hierachy involved in mammalian cell-type specification. Nature 355: 457-461.

Ladias, J.A.A., M. Hadzopoulou-Cladaras, D. Kardassis, P. Cardot, J. Cheng, V. Zannis, and C. Cladaras. 1992. Transcriptional regulation of human apolipoprotein genes ApoB, ApoCIII, and ApoAII by members of the steroid hormone receptor superfamily HNF4, ARP-1, EAR-2, and EAR-3. $J$. Biol. Chem. 267: 15849-15860.

Lai, E., V.R. Prezioso, E. Smith, O. Litvin, R.H. Costa, and J.E. Darnell Jr. 1990. HNF-3A, a hepatocyt-enriched transcription factor of novel structure is regulated transcriptionally. Genes \& Dev. 4: 1427-1436.

Lai, E., V.R. Prezioso, W. Tao, W.S. Chen, and J.E. Darnell Jr. 1991. Hepatocyt nuclear factor $3 \alpha$ belongs to a gene family in mammals that is homologous to the Drosophila homeotic gene fork head. Genes \& Dev. 5: 416-427.

Leach, R.J., M.J. Thayer, A.J. Schafer, and R.E.K. Fournier. 1989. Physical mapping of human chromosome 17 using fragmentcontaining microcell hybrids. Genomics 5: 167-176.

Lem, J., A.C. Chin, M.J. Thayer, R.J. Leach, and R.E.K. Fournier. 1988. Coordinate regulation of two genes encoding gluconeogenic enzymes by the trans-dominant locus Tse-1. Proc. Natl. Acad. Sci. 85: 7302-7306.

Lipshitz, H.D. 1992. Axis specification in the Drosophila embryo. Curr. Opin. Cell Biol. 3: 966-975.

Luckow, B. and G. Schütz. 1987. CAT constructions with multiple unique restriction sites for the functional analysis of eukaryotic promoters and regulatory elements. Nucleic Acids Res. 16: 5490.

McCormick, A., D. Wu, J.-L. Castrillo, S. Dana, J. Strobl, E.B. Thompson, and M. Karin. 1988. Extinction of growth hormone expression in somatic cell hybrids involves repression of the specific trans-activator GHF-1. Cell 55: 379-389.

Nichols, M., F. Weih, W. Schmid, C. DeVack, E. Kowenz-Leutz, B. Luckow, M. Boshart, and G. Schütz. 1992. Phosphorylation of CREB affects its binding to high and low affinity sites: Implications for cAMP induced gene transcription. EMBO I. 11: 3337-3346.
Nitsch, D., A.F. Stewart, M. Boshart, R. Mestril, F. Weih, and G. Schütz. 1990. Chromatin structures of the rat tyrosine aminotransferase gene relate to the function of its cis-acting elements. Mol. Cell. Biol. 10: 3334-3342.

Øyen, O., M. Sandberg, W. Eskild, F.O. Levy, G. Knudsen, S. Beebe, V. Hansson, and T. Jahnsen. 1988. Differential regulation of messenger ribonucleic acids for specific subunits of cyclic adenosine 3',5'- monophosphate (CAMP)-dependent protein kinase by cAMP in rat Sertoli cells. Endocrinology 122: 2658-2666.

Paro, R. 1990. Imprinting a determined state into the chromatin of Drosophila. Trends Genet. 6: 416-421.

Peterson, T.C., A.M. Killary, and R.E.K. Fournier. 1985. Chromosomal assignment and trans-regulation of the tyrosine aminotransferase structural gene in hepatoma hybrid cells. Mol. Cell. Biol. 5: 2491-2494.

Petit, C., J. Levilliers, M.-O. Ott, and M.C. Weiss. 1986. Tissuespecific expression of the rat albumin gene: Genetic control of its extinction in microcell hybrids. Proc. Natl. Acad. Sci. 83: 2561-2565.

Poli, V., F.P. Mancini, and R. Cortese. 1990. Il-6DBP, a nuclear protein involved in interleukin- 6 signal transduction, defines a new family of leucine zipper proteins related to C/EBP. Cell 63: 643-653.

Reik, A., G. Schütz, and F.A. Stewart. 1991. Glucocorticoids are required for establishment and maintenance of an alteration in chromatin structure: induction leads to a reversible disruption of nucleosomes over an enhancer. $E M B O J$. 10: 2569-2576.

Renkawitz, R. 1990. Transcriptional repression in eukaryotes. Trends Genet. 6: 192-197.

Rigaud, G., J. Roux, R. Pictet, and T. Grange. 1991. In vivo footprinting of rat TAT gene: Dynamic interplay between the glucocorticoid receptor and a liver-specific factor. Cell 67: 977-986.

Ruppert, S., M. Boshart, F.X. Bosch, W. Schmid, R.E.K. Fournier, and G. Schütz. 1990. Two genetically defined trans-acting loci coordinately regulate overlapping sets of liver-specific genes. Cell 61: 895-904.

Schreiber, E., P. Matthias, M.M. Müller, and W. Schaffner. 1989. Rapid detection of octamer binding proteins with "mini-extracts," prepared from a small number of cells. Nucleic Acids Res. 17: 6419.

Sladek, F.M., W. Zhong, E. Lai, and J.E. Darnell Jr. 1990. Liverenriched transcription factor HNF-4 is a novel member of the steroid hormone receptor superfamily. Genes \& Dev. 4: 2353-2365.

Strähle, U., G. Klock, and G. Schütz. 1987. A DNA sequence of 15 base pairs is sufficient to mediate both glucocorticoid and progesterone induction of gene expression. Proc. Natl. Acad. Sci. 84: 7871-7875.

Strähle, U., W. Schmidt, and G. Schütz. 1988. Synergistic action of the glucocorticoid receptor with transcription factors. EMBO I. 7: 3389-3395.

Thayer, M.J. and R.E.K. Fournier. 1989. Hormonal regulation of Tsel-repressed genes: Evidence for multiple genetic controls in extinction. Mol. Cell. Biol. 9: 2837-2846.

Tian, J.-M. and U. Schibler. 1991. Tissue-specific expression of the gene encoding hepatocyte nuclear factor 1 may involve hepatocyte nuclear factor 4. Genes \& Dev. 5: 2225-2234.

Weigel, D. and H. Jäckle. 1990. The fork head domain: A novel DNA binding motif of eukaryotic transcription factors? Cell 63: 455-456.

Weigel, D., G. Jürgens, F. Küttner, E. Seifert, and H. Jäckle. 1989. The homeotic gene fork head encodes a nuclear protein and is expressed in the terminal regions of the Drosophila em- 
bryo. Cell 57: 645-658.

Weih, F., A.F. Stewart, and G. Schütz. 1988. A novel and rapid method to generate single stranded DNA probes for genomic footprinting. Nucleic Acids Res. 16: 1628.

Weih, F., A.F. Stewart, M. Boshart, D. Nitsch, and G. Schütz. 1990. In vivo monitoring of a cAMP-stimulated DNA-binding activity. Genes \& Dev. 4: 1437-1449.

Weintraub, H., R. Davis, S. Tapscott, M. Thayer, M. Krause, R. Benezra, T.K. Blackwell, D. Turner, R. Rupp, S. Hollenberg, Y. Zhuang, and A. Lassar. 1991. The myoD gene family: Nodal point during specification of the muscle cell lineage. Science 251: 761-766.

Weiss, M.C. and M. Chaplain. 1971. Expression of differentiated functions in hepatoma cell hybrids: Reappearence of TAT inducibility after loss of chromosomes. Proc. Natl. Acad. Sci. 68: 3026-3030.

Weiss, M.C., R.S. Sparkes, and R. Bertolotti. 1975. Expression of differentiated functions in hepatoma cell hybrids. IX. Extinction and reexpression of liver-specific enzymes in rat hepatoma-Chinese hamster fibroblast hybrids. Somatic Cell Genet. 1: 27-40.

Weiss, M.C., D. Cassio, and C.H. Sellem. 1988. Cell differentiation: Contribution of somatic cell genetics. Cancer Surveys 7: 295-302.

Wildeman, A.G., P. Sassone-Corsi, T. Grundström, M. Zenke, and P. Chambon. 1984. Stimulation of in vitro transcription from SV40 early promoter by the enhancer involves a specific trans-acting factor. $E M B O$ I. 3: 3129-3133. 


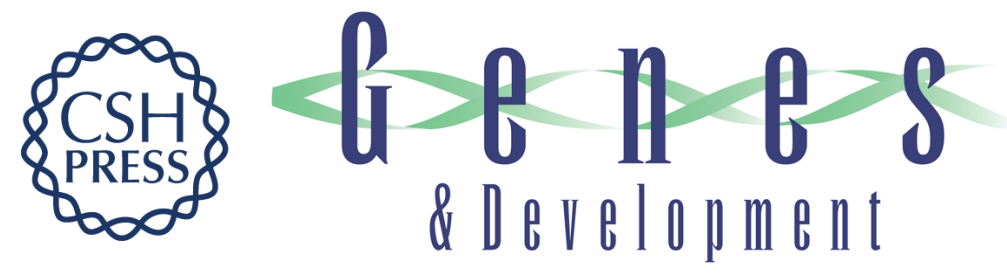

\section{Extinction of tyrosine aminotransferase gene activity in somatic cell hybrids involves modification and loss of several essential transcriptional activators.}

D Nitsch, M Boshart and G Schütz

Genes Dev. 1993, 7:

Access the most recent version at doi:10.1101/gad.7.2.308

References This article cites 67 articles, 24 of which can be accessed free at: http://genesdev.cshlp.org/content/7/2/308.full.html\#ref-list-1

License

Email Alerting Receive free email alerts when new articles cite this article - sign up in the box at the Service top right corner of the article or click here.

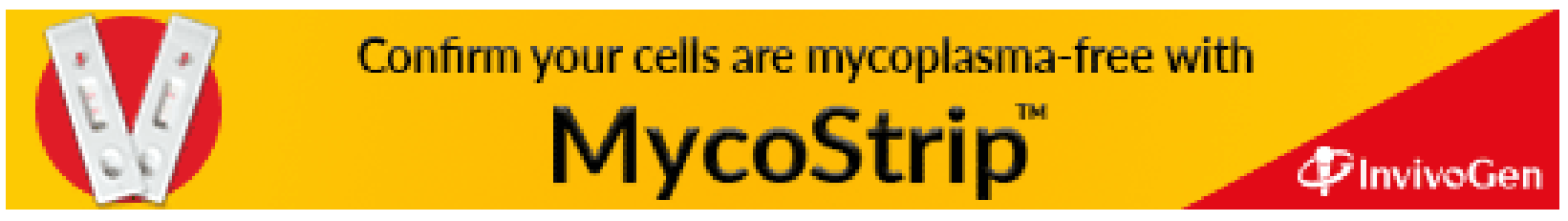

